where the range is from $59^{\circ} \cdot 9 \mathrm{~F}$, in August, to $71^{\circ} .6 \mathrm{~F}$., in February, only $11^{\circ} .7 \mathrm{~F}$., whilst at Cuzco the range is only $6^{\circ} \cdot 1 \mathrm{~F}$.

At Mollendo and La Joya, both west of the mountains, the south and east winds predominate very largely, whilst at Cuzco and Santa Ana there is no marked preponderance of wind from any particular quarter.

During the period April, I892, to December, I895, the total rainfall at Mollendo was 2.65 inches, the mean annual rainfall being 0.66 inch. At La Joya, which is in the middle of the desert of Islay, no measurable rain fell during the whole period, that is, never did more than one two-hundredth of an inch fall on any one day. On the average there are eight days per year on which some rain falls. The annual rainfall at Cuzco is 38.58 inches, and the rainfall for the year July, 1894, to June, I895, at Santa Ana was $5 \mathrm{I} \cdot 7 \mathrm{I}$ inches.

All the observations made by eye are given in full, and are well summarised. The dated remarks which accompany the tables prove very interesting reading, especially those referring to the high stations, and show well the difficulties encountered in making observations at these altitudes, exposed to wind and cold, and apparently also to robbers, for on September 6, 1894, it is recorded that at the Misti summit station the doors of the hut and shelter were found open, and that the barograph, thermometers, and tools had been stolen!

As an appendix an account is given of the moving sand dunes of the desert of Islay. Scattered over this desert are thousands of these crescent-shaped dunes. They are all of one form, and have always the same orientation, with the convex side to the south winds and the cusps pointing north and north-west.

Prof. Bailey measured one of these dunes near La Joya in 1894 . The points were 160 feet apart, and the length round the convex side was 477 feet. Its maximum width was more than roo feet, and the weight was estimated as more than 8000 tons.

Between March, I892, and March, 1894, it had travelled I25 feet, and by March, I896, a further I20 feet. From that date until January, I9or, monthly measures were taken, and in the five years it travelled 294 feet at an average rate of more than 5 feet per month. A comparison of the record of movement and the record of strong south winds shows that these winds are the sole cause of the northerly movement of these sand dunes.

W. M.

\section{THE ASSOCIATION OF ECONOMIC BIOLOGISTS}

$\mathrm{O}^{\mathrm{N}}$ Wednesday, January 9, the annual meeting of the Association of Economic Biologists opened at Cambridge, and continued until Friday, January Ir. The conferences were held by kind permission of the medical staff in the pathological department of the University, and the laboratories in this department and also the zoological laboratory were thrown open for the occasion, and members also had the opportunity of visiting the botanical department.

Mr. A. E. Shipley, F.R.S., was elected president of the association for 1907 in the place of the retiring president, Mr. F. V. Theobald, who with Sir Patrick Manson, K.C.M.G., and Prof. W. Somerville, will act as vicepresidents for the year.

In his presidential address Mr. Shipley dealt with the subject of sea fisheries. He gave an interesting account of this important subject, and dwelt on the necessity of constant investigation. No less than 27,000 vessels are engaged in this industry, employing 90,000 men, fishing from British ports, the capital invested being estimated at $11,000,000 l$. He referred to the partial failure of the herring fishery last summer, and to the numerous inquiries that had been held concerning such matters, recounting no less than seventeen in the last seventy years.

The president is of opinion that time is not yet ripe for deep-sea fishing legislation, on account of our knowledge still being so deficient that it does not yet form a sound basis for law making. The North Sea fisheries are those upon which our energies must be mainly expended. Fishermen and experts have long held that the grounds are being depleted, and the latest report of the Board of Agriculture and Fisheries bears out these statements.

Mr. Shipley then mentioned various experiments that had been carried out in Norway and on the Dogger Bank. Some interesting figures regarding fish reproduction were quoted, showing their enormous sexual powers; for instance, the turbot produced annually $8 \frac{1}{2}$ million eggs and the $\operatorname{cod} 4 \frac{1}{2}$ million.

The chief possible causes of impoverishment were summed up as follows:-(I) the accumulated stocks of the Dogger and Iceland grounds had been fished out; (2) any given area of sea could support but a limited quantity of produce; and (3) the excessive destruction of young fish. In spite of the grave nature of the North Sea problem, it is satisfactory to learn that the condition of the fishing industry generally was never more prosperous than at the present time. It is hoped that sufficient funds will be forthcoming to continue the excellent scientific work in this subject that has already been done.

Prof. Nuttall's paper on red-water fever and allied diseases was full of interesting matter. After explaining the results of his investigations into the life-history of the Piroplasmæ he dealt with the various diseases caused by them, dwelling particularly on the results of his experiments on canine piroplasmosis. In connection with this paper Prof. Nuttall and Mr. Warburton had prepared a most interesting exhibition of ticks, and the parasites they convey.

The first day's proceedings finished with a paper by $\mathrm{Mr}$. R. H. Biffen on his well-known work on cereal breeding. The first paper on Thursday was one by Mr. F. V. Theobald on some new hemipterous fruit pests. Illustrated by lantern-slides, the life-history and damage caused by leaf-hoppers (Typhlocybidæ) were fully entered into. There had been no complaint of these insects by fruit-growers until last year, when some species occurred in such numbers that they even stopped picking. Besides mentioning results obtained in the treatment of these pests, $\mathrm{Mr}$. Theobald discussed the parasites which affect the Typhlocybidæ, amongst the most interesting being some small Proctotrupids which cause "parasitic castration," one genus, Aphelopus, having occurred during the past year in such numbers that the opinion was expressed that the "hoppers" must have been nearly stamped out in places.

A long paper followed on the American gooseberry mildew, by Mr. Salmon, who explained its life-history and the great damage it does, and dwelt upon the necessity of immediate steps being taken to stamp it out and prevent importation. The paper caused some discussion, in which Profs. Middleton, Percival, and Fisher joined.

The secretary ( $\mathrm{Mr}$. Collinge) then gave a short and concise description of his successful extermination of the black-currant gall mite by means of sulphur and lime. Dr. MacDougall read a paper on parthenogenesis in the pine sawfly, and then gave an account of an extremely interesting piece of work on the length of life of Calandra granaria. At the afternoon sitting Mr. Freeman dealt with the geographical distribution of rubber plants, and incidentally stated that the output last year was 70,000 tons, valued at $30,000,000 l$. Of this, 63 per cent. came from tropical America and 34 per cent. from tropical Africa, the remainder from Asia, the output of cultivated rubber being only $\mathrm{I} \frac{1}{2}$ per cent. to 2 per cent. of the world's output.

Mr. E. R. Burdon then read a paper on the spruce-gall and larch-blight diseases caused by Chermes, and traced the connection between the two aphides and their migrations.

The day's proceedings terminated with a paper by Mr. F. V. Theobald on the insect pests of the British East Africa Protectorate, giving an account of the chief insect pests received from the Imperial Department of Agriculture. The most interesting is the diamond-back moth, which is thought to have been introduced into Africa, but which Mr. Theobald believes to be indigenous, in which Prof. Carpenter entirely agreed.

NO. I942, VOL. 75 ] 
The final sitting was held on Friday morning, January in, when papers were read by Mr. T. Strangeways, on a description of an infectious disease occurring in hares; by Mr. E. G. Fearnsides, on the blood changes in man caused by the presence of metazoan parasites, and their aid in diagnosis; and the use of an economic museum in the teaching of geography, by $\mathrm{Mr}$. W. G. Freeman. Some valuable observations were brought out in Mr. Fearnside's paper on the changes observed in the blood in parasitic attacks and the production of toxins by the parasites. Mr. Warburton exhibited an apparatus for extracting small mites, \&c., from moss, invented by Prof. Berlese, who contributed a paper on the olive-fruit fly and its treatment.

The next annual meeting will take place at Edinburgh in Easter, 1908; a meeting was also arranged for July in London.

Mr. Walter Collinge, of Birmingham University, is still continuing the secretaryship.

\section{THE PUBLIC SCHOOL SCIENCE MASTERS' ASSOCIATION.}

THE annual meeting of the Public School Science Masters' Association was held on Saturday, January I2, at the University of London, the president, the Rev. and Hon. E. Lyttelton, headmaster of Eton, being in the chair.

The president, in his address on the place of science and of literature in a general education, prefaced his remarks with the opinion that a classical headmaster had one great advantage when criticising a science lesson in that his total ignorance of the subject placed him in the position of the most backward of pupils, and enabled him to ascertain exactly when the lesson was successful in producing the required impression on the mind of the learner. In the discussion of educational matters there were the dangers of cloudiness from ignorance and of dogmatism which afforded no contribution to the discussion. Science was calculated to diminish these two dangers. By science he meant experimental study, and not the form of class demonstration sometimes, in the old days, combined with lax discipline, the object apparently being to provide a sort of agreeable change in the regular work of the schoolboy.

As now understood, general education meant that given to boys up to the age of sixteen, and the arguments following were favour of science being taken seriously before that age. It would be conceded that science aroused more interest, at least in its initial stages, than was the case with any other subject, save religion, but it was a question whether this interest did not fall off later when more brain work was required. This was so with classics. The practical question, however, was not whether science interested the boy more than did the classics, but whether science and literature should go on together. The boys who were apparent failures at classics might be found successful later in science. Huxley had said that in science young minds were brought into contact with facts. It was not so very different in the case of literature. The advantages claimed for science in educational effects, training in inductive and deductive methods, and freedom from following mere authority, were shared by most other subjects when these were taught by modern methods. These newer methods were certainly due to the influence of science teaching.

The advantages of experimental science might be said to consist in the constant application to reason, truth, the senses of touch and sight, the virtue of patience, and accuracy. Science brought the pupil into association with the great army of discoverers, and illuminated daily life with its stimulating powers, leading to the exercise of the precious faculties of imagination and wonder. The president pleaded for training leading to ambidexterity, and referred to the healthful mental effect afforded by exercise of both sides of the brain, pointing out that many school games were lacking in this respect. The results of scientific and of literary teaching both depended upon the NO. 1942, VOL. 75] enthusiasm of the teacher, but this was especially true of the latter. One advantage of literature was that it brought the learner more into contact with human affairs generally, and although some of the faculties touched were the same as in the case of science, there were others not so influenced. They were not called upon to decide between two subjects. There was room for both; teachers of science and of classics should be co-workers. Literary teachers should be able to save the science masters the labour of teaching the art of making notes in correct style. The classical failures should be rescued by science. The classical teacher called to the science teacher for help with new devices to touch the imagination and awaken hopefor something to haunt, startle, or waylay the young minds; to make them feel the joy of learning.

Sir Oliver Lodge said that to eliminate the heat retained rather than generated by cloudiness of thought and fog of dogmatism, it was necessary to admit the clear and bracing atmosphere of science. $\mathrm{He}$ agreed that ambidexterity was to be encouraged. There were three kinds of boys, the docile, the eager, and the unwilling, each of whom required different treatment. But it was necessary to consider the average boy. The quantitative side of science should not be overdone. In that respect subjects differed; in the study of heat, quantitative work was desirable in the earliest stages, but in electricity he thought it better at first to allow an acquaintance with phenomena, proceeding later to measurement. The teacher should excite interest, rouse curiosity, feed only the hungry, and not stuff with information apropos of nothing. Sir Oliver suggested that astronomy and physiology might be taken in schools, and that astronomy should be treated in a manner not too technical, but rather on biographical lines. One should begin at both ends of a subject, but in different ways, for science was both inductive and deductive, and this method of learning would use both qualities. He advocated the pupil's going "behind the scenes"; he should read examination answers, perhaps set examination papers. In learning a language a boy was apt to consider he was dealing with chaos, so many forms of words occurring, e.g. changes in stem of verbs, for which he could see no reason. Were the boy set to construct a language, he would see the necessity for and realise the meaning of tenses and cases. Boys should be encouraged to read the classics of science, and then they would get to appreciate the spirit of scientific investigation, which should be carried into all their studies. Books should be used in order to learn how to acquire knowledge at first hand; problems should be thought out before information was gratuitously supplied. A literary education was possibly best on the psychical side, but it did not give a knowledge of the material universe, and no educated person should be deprived of this.

Prof. Tilden thought the syster of classical and scientific sides in schools was insufficient. There were, for instance, artistic minds which did not respond to either of these divisions. The president, replying to $\mathrm{Mr}$. J. Talbot (Harrow), said he agreed that science should have a liberal allowance of time in the curriculum, something quite different from simply two hours per week, and in reply to the Rev. A. L. Cortie, S.J. (Stonyhurst), he advocated commencing the subject at, say, six or seven years of age. Mr. Thwaites (Wyggeston Schools, Leicester) gave the results of some inquiries he had made of the chief public schools. In general, about 60 per cent. of the boys take science, and of these about 95 per cent. are in the general courses. The average number in classes was $2 \mathrm{I} \cdot 5$ for the general and 14 for special coursès. The former were allowed, on the average, four hours per week for two subjects, and the latter twelve hours. In twentythree schools there was one science master for every seventy-six boys. He considered it was now time for the schools to agree upon the subject-matter of their science courses.

Mr. F. R. Leyland-Wilson (Charterhouse) read a paper on the best method of introducing the atomic theory in science.

An exhibition of apparatus by members and manufacturers was held at the close of the meeting. 